\title{
Building bridges in higher education: Student-faculty relationship quality, student engagement, and student loyalty
}

\author{
Ingrid Snijders $^{\mathrm{a}, \mathrm{b}, *}$, Lisette Wijnia ${ }^{\mathrm{b}, \mathrm{c}}$, Remy M.J.P. Rikers ${ }^{\mathrm{a}, \mathrm{c}}$, Sofie M.M. Loyens ${ }^{\mathrm{a}, \mathrm{c}}$ \\ ${ }^{a}$ Roosevelt Center for Excellence in Education, University College Roosevelt, Utrecht University, the Netherlands \\ ${ }^{\mathrm{b}}$ Roosevelt Center for Excellence in Education, HZ University of Applied Sciences, the Netherlands \\ ${ }^{\mathrm{c}}$ Erasmus University College, Erasmus Universiteit Rotterdam, the Netherlands
}

\section{A R T I C L E I N F O}

\section{Keywords:}

Student-faculty relationships

Relationship quality

Student engagement

Student loyalty

Higher education

\begin{abstract}
A B S T R A C T
This study's aim was to investigate a hypothesized model examining the associations between students' perceptions of the quality of their relationship with their educational faculty and staff (i.e., relationship quality) and students' involvement. The relationship quality measurement included students' experiences with all educational faculty and staff, with the aim of predicting student engagement and student loyalty. Based on data from 454 higher education students, findings indicate that affective commitment and affective conflict are important relationship quality dimensions that influence the student engagement dimensions of absorption, dedication, and vigor. The main conclusion is that a relationship management approach in higher education is fruitful to achieve positive academic outcomes such as student engagement and student loyalty.
\end{abstract}

\section{Introduction}

Research on relationships between students and their educational faculty and staff has become increasingly important due to recent developments in higher education. The use of degree completion rates to evaluate universities (Estermann \& Claeys-Kulik, 2016; Jones, 2016) or other forms of performance-based funding (Hagedorn, 2015), as well as global competition among institutions and about their rankings (Chirikov, 2016; Elken, Hovdhaugen, \& Stensaker, 2016), and increasingly customer-like behavior by students (Woodall, Hiller, \& Resnick, 2012), all bring a focus on developing positive relationships with higher educational stakeholders to the fore. Positive student-faculty relationships in higher education can contribute to students' involvement and achievement (Umbach \& Wawrzynski, 2005); they have been shown to be related to higher student retention rates (O'Keeffe, 2013), better academic performance (Klem \& Connell, 2004), sense of school belonging (Wong, Parent, \& Konishi, 2019), and decreased student drop-out rates (Klem \& Connell, 2004). Because positive student-faculty relationships can lead to engaged students who enjoy studying and therefore might be connected to their educational faculty and staff during and after graduation, they deserve the attention of higher education institutions (HEIs; Atnip, 2015).

Prior educational research on student-faculty or teacher-student relationships has demonstrated that these relationships, when perceived positively, can lead to positive outcomes (e.g., Kim \& Sax, 2009; Kim \& Schallert, 2011; Veldman, Van Tartwijk, Brekelmans, \& Wubbels, 2013). For instance, a recent qualitative study in a primary school setting by Lee (2012), showed that encouragement and support from teachers as well as respect are important to foster students' participation in education. In an earlier study conducted in secondary education, Wubbels and Brekelmans (2005) focused on teacher behavior. They indicated that investigating teacher interaction with students might be useful for evaluating students' perceptions of the teacher-student relationship.

\footnotetext{
* Corresponding author at: Roosevelt Center for Excellence in Education, Middelburg, the Netherlands.

E-mail address: i.snijders@ucr.nl (I. Snijders).
} 
In higher education, Kim and Lundberg (2016) used a structural equation modeling approach to examine associations between student-faculty interactions, classroom engagement, and cognitive skills development. Their research indicated, among other things, that "student-faculty interaction is related to greater levels of classroom engagement" (p. 288). Some other studies have focused on one or a few aspects of student-faculty relationships, such as the frequency of interactions (Cotten \& Wilson, 2006) or on formal/ informal interactions (Meeuwisse, Severiens, \& Born, 2010). Nevertheless, the need to further investigate the consequences of the quality of relationships between students and their educational faculty/staff still remains (Bowden, 2011; Hagenauer \& Volet, 2014; Hennig-Thurau, Langer, \& Hansen, 2001). This study addresses this knowledge gap. The goal is to examine how HEIs can build and sustain relationships by emphasizing aspects of the quality of relationships between students and their educational faculty/staff. HEIs may be better able to influence positive academic involvement if they understand the mechanisms through which student-faculty relationship quality affects student engagement and, in turn, student loyalty (Taylor \& Parsons, 2011).

Gaining such valuable insight for HEIs into the attitudinal and behavioral processes determining student involvement, such as student loyalty (Buttle \& Maklan, 2015), is essential in the current context. Loyal behavior could be expressed by students' intentions to continue with their studies, but also by their giving positive recommendations to potential future students. This kind of student behavior is essential for the continuity and growth of HEIs. Therefore, possible predictors of students' supportive behaviors should be further considered and investigated to help HEIs and educational practitioners to gain better insight into what the relationship between student and faculty holds, and how relationship quality aspects might contribute to students' engagement in learning and student loyalty intentions. To our knowledge, few studies exist on this topic.

The present study addresses this issue by using a consumer-focused approach. The concept of 'consumer' is context-related. For example, in business-to-business relations, consumers or customers are called buyers, while in commercial services such as life insurance, customers are called clients, and in health care, they are called patients. While rarely applied to institutions of higher education ( $\mathrm{Ng} \&$ Forbes, 2009), measurement of relationship quality as defined in consumer services is also applicable to the higher education context (Snijders, Rikers, Wijnia, \& Loyens, 2018; Snijders, Wijnia, Rikers, \& Loyens, 2019; Bowden, 2011; Hennig-Thurau et al., 2001). Although the 'student as consumer' approach is still debated in the literature (see, Bunce, Baird, \& Jones, 2017; Tomlinson, 2017), students can be seen as the main recipients of educational services (Braun \& Zolfagharian, 2016).

Using the lens of social exchange theory, we developed our hypothesized model based on Crosby, Evans, and Cowles's (1990) theoretical framework linking service relationships to organizational outcomes. The relationship and services management literature explicitly focus on building and maintaining relationships with customers (Bowden, 2009; Grönroos, 1994; Gummesson, 1994). Relationships between provider and consumer are essential in the service delivery process to establish engagement and loyalty (Zeithaml, Bitner, \& Gremler, 2009). The customer's evaluation of the interpersonal relationship with the contact person has a significant influence on the continuation of the existing service relationship (i.e., customer retention; Macintosh, 2007), and thus, the organization's continuity and/or growth. In other words, positioning students as key participants in the educational service experience (Braun \& Zolfagharian, 2016) implies that HEIs should attend to nurturing students and the institution's relationships with them. Just like customers' evaluations, students' perceptions of the quality of the relationship they have with their educational faculty/staff should also be considered. In higher education, positive interactions between students and their faculty and staff could have a positive influence on student development and involvement (Hu, Hung, \& Ching, 2014; Kim \& Sax, 2009; Kuh \& Hu, 2001). In turn, students' perceptions of the quality of their relationships with educational faculty and staff (i.e., relationship quality) which is based on these interactions, might result in student engagement (Bowden, 2009) and student loyalty (Hennig-Thurau et al., 2001).

\subsection{Student-faculty relationship quality}

The definition of relationship quality varies according to the research context (Osobajo \& Moore, 2017), however, the existing relationship quality literature "suggests that relationship quality is widely used to describe how healthy a relationship is based on the evaluation or assessment of the parties within that relationship" (p. 4). Thus, relationship quality considers a party's overall perception or judgement of the quality of the relationship he or she is in. In a services context, the emphasis is on the intangible aspects of on-going (relational) interactions (Roberts, Varki, \& Brodie, 2003). Hence, in such a context the concept of relationship quality is focused on enduring relationships, which is similar to student/faculty relationships in higher education. The relationship quality construct includes five relationship quality dimensions (Roberts et al., 2003). Based on the relationship quality research by Snijders and colleagues $(2018,2019)$ ), Roberts et al. (2003) applied these dimensions in the context of higher education where they represent: students' trust in educational faculty/staff's honesty, students' trust in educational faculty/staff's benevolence, students' affective conflict, students' affective commitment, and students' overall satisfaction related to their educational faculty/staff's performance (Snijders et al., 2018, 2019).

Trust is directed toward two essential elements: honesty and benevolence (Kumar, Scheer, \& Steenkamp, 1995). Trust in honesty refers to the trust students have in a university's credibility. It concerns students' perceptions of the staff and faculty's sincerity and whether they will perform their role effectively and reliably. Furthermore, students' perceptions of trust in the honesty of educational staff is based on the extent to which they believe educational faculty and staff's word can be relied on. Trust in benevolence (willingness to help) refers to the extent to which students believe staff and faculty are concerned about students' welfare, including having intentions and motives beneficial to students, and avoiding acting in a way that will result in negative outcomes for students.

Affective conflict is a negative indicator of relationship quality (i.e., lack of trust). Students can also evaluate their relationships with faculty and staff based on the conflicts they perceive, which will lower levels of perceived relationship quality. It is used as an indicator of the retained level of conflict felt by students concerning their relationship with university faculty and staff (e.g., irritation, frustration, and anger). 
Affective commitment refers to students' feelings of wanting to belong or be connected to their educational faculty and staff. In relationship management literature, relationship commitment represents the confidence one has in a service provider's reliability and integrity (see, e.g., commitment-trust theory; Morgan \& Hunt, 1994), and serves as a precursor to a loyal attitude (see, e.g., Dick \& Basu, 1994). Students' affective commitment develops over time as they become accustomed to positive responses from faculty and staff, leading them to become more and more secure in the relationship they have with their educational faculty and staff.

Satisfaction reflects the cumulative student satisfaction with the overall quality of the student/faculty relationship, such as students' cognitive and affective evaluation based on their personal experience across all educational service encounters (i.e., every time a student interacts with someone from their university).

Educational research indicates that students' perceptions of relationship quality might positively influence student development and outcomes (Astin, 1993; Kuh \& Hu, 2001), such as academic performance (Pascarella, Terenzini, \& Hibel, 1978). A key contribution by Hennig-Thurau et al. (2001) took a relationship management approach, and implied that higher quality of student-faculty relationships (i.e., relationship quality) led to higher levels of student loyalty, for example, students' positive recommendations. Furthermore, recent studies (see, Xerri, Radford, \& Shacklock, 2017) have supported the suggestion that these relationships play "a pivotal role in the very process of engagement" (Pianta, Hamre, \& Allen, 2012, p. 366).

\subsection{Student engagement}

Previous studies have examined the concept and importance of engagement extensively in educational settings (e.g., Bakker, Sanz Vergel, \& Kuntze, 2015; Betts, Appleton, Reschly, Christenson, \& Huebner, 2010; Fredricks \& McColskey, 2012; Jang, Reeve, \& Deci, 2010) and management settings (e.g., Bowden, 2009; Jarvis, Halvorson, Sadeque, \& Johnston, 2014; Van Doorn et al., 2010; Verhoef, Reinartz, \& Krafft, 2010). Yet, the theoretical understanding and conceptualizations of engagement remain fragmented and untested (Kahu, 2013). According to the perspective adopted in this study, student engagement in the context of higher education can best be defined as a positive, fulfilling, work- (study-) related state of mind that is characterized by vigor, dedication, and absorption (Bakker et al., 2015; Schaufeli, Martinez, Marques Pinto, Salanova, \& Bakker, 2002). The student engagement scale developed by Schaufeli et al. (2002) was previously investigated by them in a higher educational context, examining the student engagement dimensions of vigor, dedication, and absorption. These student engagement dimensions can be described as follows (Schaufeli \& Bakker, 2003): vigor is characterized by high levels of energy and mental resilience while working, the willingness to invest effort in one's work, and persistence even in the face of difficulties. Dedication refers to being strongly involved in one's work and experiencing a sense of significance, enthusiasm, inspiration, pride, and challenge. Finally, absorption is characterized by being fully concentrated and happily engrossed in one's work, whereby time passes quickly and one has difficulties detaching oneself from work (Schaufeli, Bakker, \& Salanova, 2006). With these three dimensions, all aspects of engagement are captured: behavioral, emotional/affective, and cognitive engagement (Fredricks, Filsecker, \& Lawson, 2016).

The assumption is that the better the educational experience students have through higher relationship quality, the more they will be engaged with their studies. Engagement, in turn, can positively influence students' involvement in academic, social, or extracurricular activities. Therefore, engagement is considered crucial for achieving positive academic outcomes such as degree completion and for showing the outcome of positive relationships between students and their educational faculty/staff (Connell \& Wellborn, 1991), namely, student involvement and supportive behavior outside the classroom. The latter can also be captured under the concept of "student loyalty" (Bowden, 2009).

\subsection{Student loyalty}

In the international literature on student behavior, student loyalty is increasingly considered to be a critical measure of the success of HEIs (Rojas-Mendez, Vasquez-Parraga, Kara, \& Cerda-Urrutia, 2009). Student loyalty refers to the extent to which students feel connected to the institution and how attitudes and/or behaviors express this connection (Nesset \& Helgesen, 2009). Loyalty has two aspects: attitude and behavior (Hallowell, 1996). In higher education, loyal attitude may refer to the (positive) feelings students have related to their faculty/staff and/or university. Student loyalty is expressed in loyalty intentions and behavior during and/or after their enrollment period, for example, (positive) recommendations from students about their educational faculty/staff, and/or university, or active participation in extracurricular activities. HEIs benefit from loyal and successful students in terms of their involvement. Prior research has shed some light on student loyalty by investigating its relationship with positive word-of-mouth about the institution (Alves \& Raposo, 2007) and commitment towards the institution (Perin, Sampaio, Simões, \& de Pólvora, 2012). Other studies have examined possible student loyalty drivers such as trust, commitment, quality of facilities, perceived value/quality, service quality, and image (e.g., Brown \& Mazzarol, 2009; Carvalho \& de Oliveira Mota, 2010; Nesset \& Helgesen, 2009). Thus, universities need to cultivate good relationships with their students to foster students' supportive behavior, such as positive recommendations or donations by students and/or alumni (Sung \& Yang, 2009).

\subsection{Present study}

The aim of this study is to provide new insight into relationship quality (as expressed in the identified dimensions) as a predictor of student engagement (as expressed in the identified dimensions) and student loyalty. The assumption is that high quality relationships between students and faculty/staff positively influence students' involvement in terms of their engagement and loyalty. To investigate this assumption, we used a relationship quality instrument used in consumer services research, which we adapted and 
validated in previous studies and found to be applicable in higher education (Snijders et al., 2018; Snijders et al., 2019). While other studies have taken a qualitative approach, such as focus group studies where the emphasis is on interactions within or outside the classroom (e.g., Cotten \& Wilson, 2006; Kuh \& Hu, 2001), or considered only the teacher-student relationship (e.g., Fraser \& Walberg, 2005), this study has a quantitative design for testing a model of the relations between relationship quality, student engagement, and student loyalty. We used an instrument evaluating relationship quality in higher education that included students' experiences with all educational faculty and staff. This study contributes in several ways to the existing literature on student/faculty relationships.

First, within this study, the approach was to investigate relationship quality applying five distinct, but related dimensions, thereby covering the relationship quality construct as a whole. We believe we therefore, provide a more specific view of relationship quality in higher education. Our study differs from previous relationship quality studies (e.g., Hennig-Thurau et al., 2001), where the examination of relationship quality among alumni included trust, commitment, and perceived quality of teaching services, leaving out other important relationship quality dimensions. Moreover, although we value the relationship quality research among alumni, in line with Snijders and colleagues (2019) to overcome the limitations of retrospective research, the present sample consisted of enrolled students.

Second, instead of solely focusing on part of the student-faculty relationship, such as student/faculty interactions (see, Kim \& Lundberg, 2016), the present study investigated the quality of the relationship between students and their educational faculty/staff. This is different from other studies. We believe that when asking students about their relationship quality, all persons related to their education should be included. In other words, perhaps the teacher is not always the most important contact person. Therefore, relationship quality perceptions regarding all educational faculty and staff should be considered.

Third, we hypothesized that when students perceive themselves to have relationships with their educational faculty and staff, relationship quality aspects act as predictors of their engagement in their studies, and (in)directly of their loyalty intentions. This study is one of the first attempts to capture a broader idea of how relationship quality contributes to building relationships with enrolled students that can lead to positive educational consequences. More engaged students might be happier at school enjoying their studies. One can imagine that overall, engaged students are less likely to drop out from school, which is good for students, parents, and HEIs. According to relationship management theory, loyal students, like any other type of customer, are necessary for the continuity and growth of the HEI or university.

The research question that guided this study was: To what extent do relationship quality dimensions (in)directly and positively relate to student engagement and student loyalty? We hypothesized that having high quality relationships with educational faculty/ staff will positively influence students' student engagement and, in turn, their attitudinal and/or behavior loyalty. Therefore, possible drivers of student loyalty were examined (see Fig. 1). Employing partial least squares structural equation modeling (PLS-SEM), we tested the following hypotheses:

1 Relationship quality dimensions (a-e) will be positively related to student engagement (e.g., Taylor \& Parsons, 2011; Xerri et al., 2017);

2 Student engagement dimensions (a-c) will be positively related to student loyalty (e.g., Bowden, 2009);

3 Relationship quality dimensions (a-e) will be positively related to student loyalty (for reasons of clarity, these relations were not depicted in Fig. 1);

4 Student engagement dimensions will mediate the relation between relationship quality dimensions (a-e) and student loyalty (for reasons of clarity, these relations were not depicted in Fig. 1).

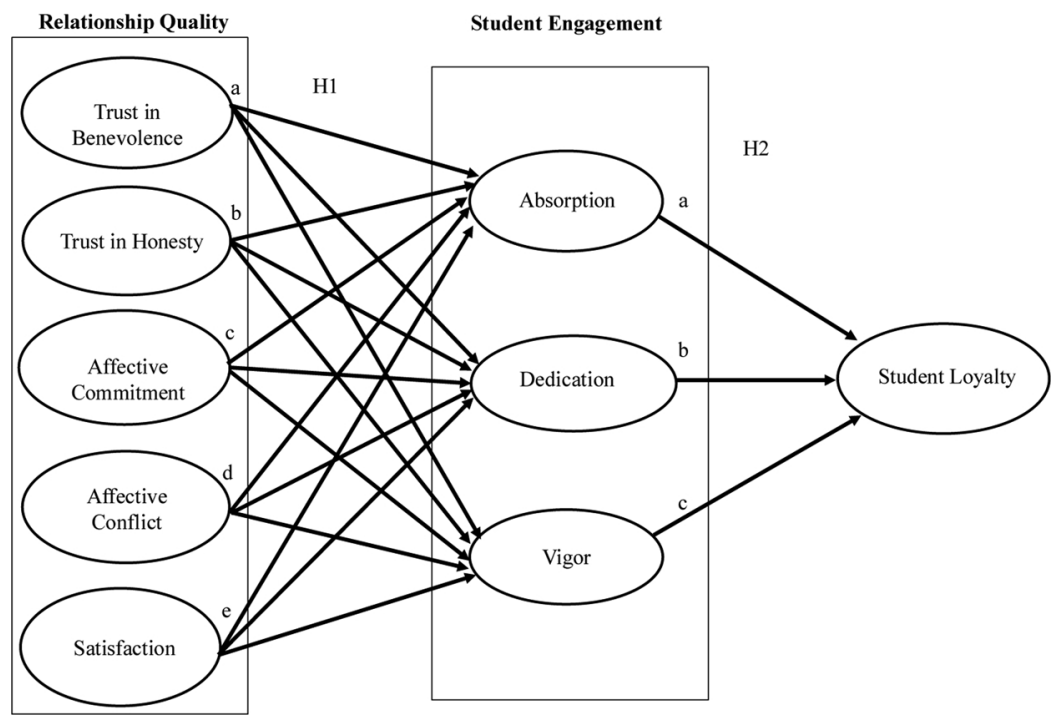

Fig. 1. Hypothesized Model.

Note: For reasons of clarity, $\mathrm{H} 3$ and $\mathrm{H} 4$ are not depicted in the model. 


\section{Method}

\subsection{Pilot study}

The hypothesized model was pretested in a pilot study. Participants were 271 students in higher education $\left(M_{\text {age }}=23.19, S D_{\text {age }}\right.$ $=6.87$, female $=91.5 \%)$ attending a four-year pedagogy program $(n=106)$ or a social work program $(n=165)$. Main results suggested that the relationship quality dimensions of affective commitment and affective conflict had a statistically significant association with the student engagement dimension of dedication. In turn, dedication had a statistically significant association with student loyalty. The pilot study was followed up by further examining and validating these findings using a more diverse sample, namely, higher education students from a broader range of academic departments.

\subsection{Participants}

Participants were 454 higher education students $\left(M_{\mathrm{age}}=21.81, S D_{\mathrm{age}}=5.27\right.$, female $\left.=64.80 \%\right)$ from a Dutch university of applied sciences located in the southwest of the Netherlands, having an enrollment of approximately 4500 students. Participants responded to a solicitation to complete an online survey. Respondents were distributed across all years of study (19.8 \% first year; $19.6 \%$ second year; $24.7 \%$ third year; $25.1 \%$ fourth year), and three fields of study (31.28 \% technical department; $27.31 \%$ economics department; $41.41 \%$ social department).

\subsection{Procedure}

A link to an online survey was distributed through campus email. The survey could be completed at home or on campus. To help boost the response rate, students were encouraged to complete the survey during one of their classes (i.e., the instructor brought the survey to students' attention; instructions were given in the email and survey's introduction). Students were instructed that participation was voluntary. They were told that there were no right or wrong answers to the items, as long as their answers reflected their personal opinions. Completing the survey took approximately fifteen minutes. Students were given two months to respond. Students who did not complete the online survey were reminded by email.

The survey was made up of several parts (different questionnaires). The questionnaire items for relationship quality and student loyalty were tested using a forward-backward translation procedure (from English to Dutch to English). The set of items asking about student engagement were taken from a student engagement questionnaire that was already available in Dutch and had been tested in a higher education context by Schaufeli and Bakker (2003). To give students the opportunity to comment on the survey in general, or specifically on parts of the survey, an open-ended question was added for that purpose.

Ethical approval was obtained in accordance with the policy of the institution under study. The research project was covered by the Netherlands Code of Conduct for Research Integrity and was previously reviewed and approved by a committee from the Dutch Organization for Scientific Research. All participants were asked for informed consent via a question in the online survey. Their responses were voluntary. Only participants who gave their permission to use their answers for research were included within this study's analyses. Students' responses were treated anonymously and were not traceable by their institution to individual students.

\subsection{Materials}

To measure the constructs under study, existing scales were used (see Table 1 for items associated with each construct and scale reliabilities).

\subsubsection{Student-faculty relationship quality}

Relationship quality was measured by a 15-item questionnaire adapted from an existing relationship quality scale with a fivefactor structure: trust in honesty, trust in benevolence, affective conflict, affective commitment, and satisfaction (Roberts et al., 2003). The measurement instrument was tested in a previous study and found to be applicable in a higher education context (Snijders et al., 2018). Students were asked to indicate on a 7-point Likert scale how much they agreed with various statements, ranging from 1 (strongly disagree) to 7 (strongly agree).

\subsubsection{Student engagement}

Student engagement was measured by 9 items from the Utrecht Work Engagement Scale-Student shortened version (UWES-S-9; Schaufeli \& Bakker, 2003) with a three-factor structure: vigor, dedication, and absorption. Students were asked to indicate how they experienced their education in terms of their own vigor, dedication, and absorption on a 7-point Likert scale, ranging from 1 (almost never/a few times a year or less) to 7 (always/every day).

\subsubsection{Student loyalty}

Five items measured student loyalty (adopted from Hennig-Thurau et al., 2001); students indicated their level of agreement using a 7-point Likert scale ranging from 1 (do not agree) to 7 (do agree). 
Table 1

Construct Items Measurement Model.

Relationship quality dimensions ${ }^{\text {a }}$

/staff's benevolence $(C R=94, C A=91, A V E=85)$

My faculty/staff is concerned about my welfare (RQT B01)

When I confide my problems to my faculty/staff, I know they will respond with understanding (RQT_B02)

I can count on my faculty/staff considering how their actions affect me (RQT_B03)

Trust in faculty/staff's honesty $(C R=.93, C A=.89, A V E=.82)$

My faculty/staff is honest about my problems (RQT_HO1) ${ }^{\mathrm{d}}$

My faculty/staff has high integrity (RQT_H02)

My faculty/staff is trustworthy (RQT_HO3)

Affective commitment $(C R=.94, C A=.90, A V E=.83)$

I feel emotionally attached to my faculty/staff (RQACOMMO1)

I continue to interact with my faculty/staff because I like being associated with them (RQACOMMO2)

Affective conflict $(C R=.95, C A=.91, A V E=.85)$

I am angry with my faculty/staff (RQACONO1)

I am frustrated with my faculty/staff (RQACONO2)

I am annoyed with my faculty/staff (RQACONO3)

Satisfaction $(C R=.96, C A=.94, A V E=.90)$

I am delighted with the performance of my faculty/staff (RQSAT01) .95

I am happy with my faculty/staff's performance (RQ SATO2) 95

I am content with my faculty/staff's performance (RQSAT03)

Student engagement dimensions ${ }^{\mathrm{b}}$

Absorption $(C R=.83, C A=.72, A V E=.62)$

Times flies when I am studying (AB01)

I am immersed when I'm studying (ABO3)

Dedication ( $C R=.91, C A=.85, A V E=.76)$

I find the studying that I do full of meaning and purpose (DE01)

My studying inspires me (DE2)

I am proud of the studying that I do (DEO3)

Vigor $(C R=.89, C A=.81, A V E=.72)$

At the university, I feel bursting with energy (VIO1)

At the university, I feel strong and vigorous (VIO2)

When I get up in the morning, I feel like going to school (VIO3)

Student loyalty ${ }^{\mathrm{c}}(C R=.89, C A=.89, A V E=.69)$

If I were faced with the same choice again, I'd still choose the same university (SLO5)

Note. $\mathrm{CR}=$ composite reliability, $\mathrm{CA}=$ Cronbach's alpha, AVE = Average Variance Extracted. $N=454$.

a. Adapted from Roberts et al. (2003). b. Adopted from Schaufeli and Bakker (2003). c. Adopted from Hennig-Thurau et al. (2001).

\subsection{Analyses}

Partial least squares structural equation modeling (PLS-SEM) using SMART-PLS (Ringle, Wende, \& Becker, 2015) was conducted to analyze the data based on the hypothesized model. PLS-SEM is primarily used to develop theories in exploratory research; for example, it can be used when the focus when examining the model is on explaining the variance in the dependent variables. The goal is predicting target constructs or identifying key 'driver' constructs (Hair, Hult, Ringle, \& Sarstedt, 2016), as with relationship quality in the current study. Our primary objective in applying structural modeling is prediction and explanation of the constructs under study. Therefore, we preferred to use PLS-SEM because this study's research objective is theory development and explanation of variance (i.e., prediction of the constructs). PLS-SEM is used to develop theories in exploratory research (Hair, Hult, Ringle, \& Sarstedt, 2017) as a prediction-oriented variance-based approach that focuses on endogenous constructs/dependent variables (i.e., student engagement, and student loyalty) and aims at maximizing their explained variance by exogenous constructs (i.e., relationship quality dimensions).

A two-stage approach was followed in the analysis. First, testing of the measurement model was conducted. Next, analysis of the structural model followed, using a bootstrapping procedure with relationship quality as an exogenous latent variable, student 
engagement as an endogenous latent —mediating-variable, and student loyalty modeled as an endogenous latent variable (as depicted in Fig. 1).

\subsubsection{Measurement model}

Assessment of the measurement model was based on internal consistency reliability, convergent, and discriminant validity, and is reported for every construct within the PLS model. To assess convergent validity, we tested the significance and analyzed the magnitude of each indicator's loading on its intended latent variable (Anderson \& Gerbing, 1988).

\subsubsection{Structural model}

Evaluation of the structural model was assessed by $R^{2}$, significance of estimated values for path relationships, and effect sizes for each effect (Cohen, 1998). Assessment of the structural model was done by applying a bootstrapping procedure (Hair et al., 2016) to assess the significance of path coefficients, using 5000 bootstrap samples, no sign change included. $R^{2}$ values were assessed, with $R^{2}$ values of $0.25, .50$, or 0.75 considered to be weak, moderate, and substantial, respectively (Hair et al., 2016). Effect sizes $\left(f^{2}\right)$ were examined to indicate the exogenous construct's contribution to the endogenous latent variable's $R^{2}$ value.

\subsubsection{Mediator analysis}

To verify whether student engagement mediates the relation between relationship quality dimensions and student loyalty, a mediator analysis procedure was followed (Hair et al., 2016). First, we determined whether the direct effects from relationship quality dimensions on student loyalty were significant. Second, after including the mediating variables (vigor, dedication, and absorption), we examined the significance of the indirect effects.

\section{Results}

\subsection{Measurement model}

Assessment of the measurement model showed that all items corresponding with each relationship quality dimension and each student engagement dimension loaded on the intended constructs. Outer loadings (i.e., the estimated relationships in reflective measurement models represented by the arrows from the latent variable to its indicators that determine an item's contribution to its assigned construct) for relationship quality ranged from 0.78 to 0.95 .

Construct reliability was acceptable for all latent variables (i.e., relationship quality, student engagement, and student loyalty), as indicated by composite reliability and Cronbach's alpha values exceeding .70. Convergent validity was verified with AVE values for all constructs that were greater than the threshold value of .50 (Fornell \& Larcker, 1981). AVE values, outer loadings of the construct items from the measurement model, and composite reliability for each scale are included in Table 1.

Finally, discriminant validity was tested by comparing the square root of the AVE of each construct to its correlations with the other latent constructs (i.e., Fornell-Larcker criterion). For every pair of latent variables, the square root of the AVE was higher than the correlation between the variables, thus indicating acceptable discriminant validity (Fornell \& Larcker, 1981; see Table 2).

\subsection{Structural model}

Assessment of the structural model showed $R^{2}$ values that are reasonable for an exploratory study: the structural model explained $55 \%$ of the variance in student loyalty; for student engagement, the explained variance was $31 \%$ for absorption, $45 \%$ for dedication, and $37 \%$ for vigor. Trust in benevolence did not have a statistically significant association with any dimension of student engagement (H1a). Trust in benevolence had a statistically significant association with dedication (H1b), but not with absorption and vigor. Affective conflict had a (negative) association with absorption and vigor (H1c), but not with dedication. Affective commitment had a statistically significant association with all student engagement sub-dimensions, that is, vigor, dedication, and absorption (H1d).

The student engagement dimension of absorption did not have a statistically significant association with student loyalty (H2a).

Table 2

Construct Correlations.

\begin{tabular}{|c|c|c|c|c|c|c|c|c|c|c|}
\hline & & 1 & 2 & 3 & 4 & 5 & 6 & 7 & 8 & 9 \\
\hline 1. & RQT_B & .92 & & & & & & & & \\
\hline 2. & RQT_H & .76 & .90 & & & & & & & \\
\hline 3. & RQ_ACOMM & .64 & .58 & .91 & & & & & & \\
\hline 4. & RQ_ACON & -.49 & -.45 & -.37 & .92 & & & & & \\
\hline 5. & RQ_SAT & .73 & .71 & .60 & -.53 & .95 & & & & \\
\hline 6. & SE_AB & .42 & .35 & .55 & -.30 & .37 & .83 & & & \\
\hline 7. & SE_DE & .51 & .52 & .64 & -.37 & .52 & .76 & .87 & & \\
\hline 8. & SE_VI & .41 & .37 & .46 & -.43 & .43 & .77 & .69 & .85 & \\
\hline \multirow[t]{3}{*}{9.} & SL & .66 & .67 & .70 & -.50 & .69 & .56 & .73 & .58 & .83 \\
\hline & Mean & 5.32 & 5.37 & 5.01 & 4.78 & 4.99 & 4.32 & 5.32 & 4.30 & 5.28 \\
\hline & $S D$ & 1.33 & 1.17 & 1.44 & 1.52 & 1.34 & 1.26 & 1.23 & 1.23 & 1.36 \\
\hline
\end{tabular}




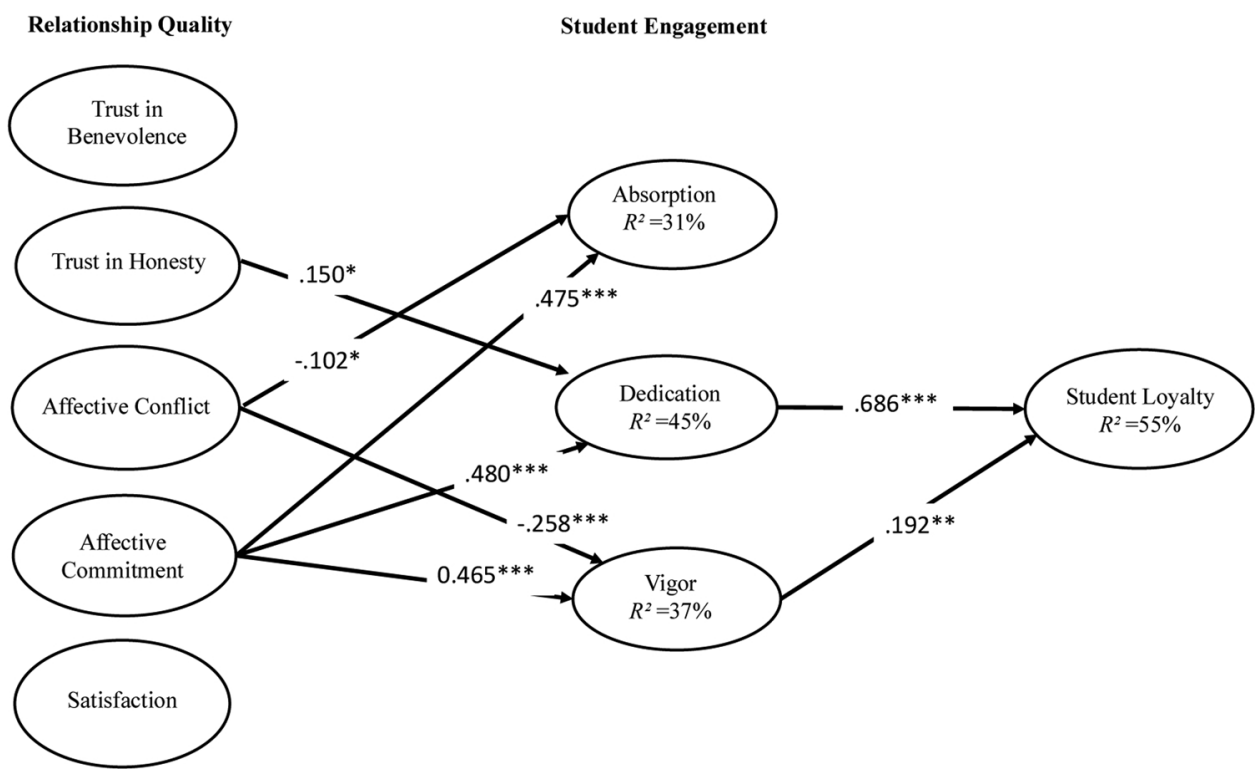

Fig. 2. Path model and PLS-SEM estimates.

Note: $N=454$ samples: ${ }^{* * *} p<.001,{ }^{* *} p<.01,{ }^{*} p<.05, \rightarrow=$ significant path.

Dedication as well as vigor had a statistically significant association with student loyalty (H2b \& c). Fig. 2 shows the diagram of the path model including statistically significant path loadings and significance levels.

Effect sizes $f^{2}$ range from weak $(<.02)$ to small $(>.02)$ to medium (.15) to large (.35; Cohen, 1988). In this study, large effect sizes were found for affective commitment on absorption, dedication, and vigor, and for dedication on student loyalty. Affective conflict had a medium (negative) effect on vigor, and vigor had a medium effect on student loyalty.

\subsection{Mediator analysis}

Direct effects of relationship quality dimensions on student loyalty (H3 a-e) were found for affective commitment $(.382, p<$ .001 ), affective conflict $(-.130, p<.001)$, satisfaction $(.221, p<.001)$, and trust in honesty $(.224, p<.001)$. No direct effect was found for trust in benevolence (see Table A1 in Appendix A). Hence, we continued the mediator analysis by further examining the indirect effects and direct effects following the procedure by Hair et al. (2017).

When including the mediation variables of dedication, vigor, and absorption, the analysis showed that affective commitment had positive indirect effects on student loyalty as well as affective conflict (i.e., a negative sample mean value for an inverse relation according to the hypothesized model, see Fig. 2). In the relation between affective commitment, affective conflict on the one hand and student loyalty on the other, both indirect and direct effects (after including the mediating variables) were found to be significant through student engagement's dedication. The direct effect of satisfaction on student loyalty disappears when including the mediating variables, though none of the indirect effects of satisfaction on student loyalty through student engagement's dimensions are statistically significant. For the relation between trust in honesty and student loyalty, de direct effect disappears when including the mediating variables, however, the indirect through dedication is significant (see Table A1 in Appendix A).

\section{Discussion}

Relationship quality deserves attention in higher education because students can be seen as one of the main stakeholders of HEIs (Bowden, 2011; Temmerman, 2018; Woodall et al., 2012). Students' perspectives should be taken into account when investigating what relational quality aspects are important for building positive relationships with them. Establishing positive relationships might lead to positively engaged and loyal students. Using this study's design, the hypotheses were party confirmed: the hypothesized model with relational quality as an exogeneous latent variable explained $31 \%$ of the variance in the student engagement dimension of absorption, 45 $\%$ in the student engagement dimension of dedication, $37 \%$ in the student engagement dimension of vigor, and, $55 \%$ in student loyalty.

\subsection{Relationship quality}

The relationship quality construct was measured with five different, but related dimensions. Therefore, care should be taken when interpreting the results for each relationship quality dimension apart from the other relationship quality dimensions. However, we tried to interpret the findings for each relationship quality dimension separately, because this might give a more detailed view of the configuration of a relational approach that educational practitioners could apply. 


\subsubsection{Trust in benevolence}

Trust in benevolence did not have a statistically significant association with student engagement (H1a). One explanation might be that the degree of educational faculty/staff's willingness to help students (e.g., show concern and respond with understanding) does not always positively influence students' experience as far as their studying. Students might evaluate the expression of educational faculty/staff's benevolence in a distinct way. In other words, students' ideas about willingness and helpfulness are perhaps different from 'benevolent' actions by educational faculty/staff. This in line with Tschannen-Moran and Gareis (2015) who pointed out with regard to the principal-teacher relationship that 'the perception of benevolence (also) involves cognitive judgment of the behaviors of others and one's experiences with them' (p. 260) and these might not be in sync with each other. However, this view is not always supported. For instance, in a recent interview with Wentzel (2018), she indicated that with young adolescents, "if a student feels that a teacher cares about them [students] and is going to be supportive of them as an individual [student], they [students] are more likely to listen to the teacher and to engage in what the teacher wants them to do". Further research is needed to support this idea.

\subsubsection{Trust in honesty}

Trust in honesty had a statistically significant association with dedication (H1b). The more positively students perceive their educational faculty/staff's honesty, the more positively they engage in their studies. In a similar way, recent organizational research highlights the importance of building trust to enhance work engagement (see, McManus \& Mosca, 2015). Furthermore, to build and maintain reciprocal relationships Wilkins (2018) in a recent study within a healthcare environment, indicated trust to be essential. We believe that is similar to higher education, where there is also an 'imbalance of power' within the relationship; for a student to become engaged, development of trust is essential, especially by showing honesty. It could be that students who appreciate faculty/ staffs' honesty might also feel loyal to their educational faculty and staff, however, the causal part is still unclear and need to be further investigated in longitudinal studies.

\subsubsection{Affective conflict}

Affective conflict had a statistically significant association with student engagement's dimensions of absorption and vigor (H1c). Affective conflict addresses negative affective/emotional aspects of relationship quality. The more conflict (e.g., irritations or frustrations students feel during their studies), the less positive students might feel. Contrary to the findings in the pilot study, which had a narrower sample as far as gender, year of study, and educational program, in this study the degree of conflict during students' studies did not affect students' dedication to their studies. This is in line with a similar study among alumni (Snijders et al., 2019). Also, a statistically significant association was found for the relation between affective conflict and student loyalty (direct effect).

\subsubsection{Affective commitment}

Affective commitment had a statistically significant association with all dimensions of student engagement (H1d), and with student loyalty (direct effect). Affective commitment also addresses affective/emotional aspects of relationship quality. Within this study's sample, perhaps that for students to be "dedicated" to something or someone, there must be some sort of relatedness or feelings of belonging and/or affection as a middle ground to eventually establish loyalty. In other words, affective commitment (as part of relationship quality) might precede dedication (as part of student engagement), which in turn precedes student loyalty (towards students' faculty/staff and the course of studies). These ideas are in line with Morgan and Hunt's (1994) commitment-trust theory, where they posited that commitment is central for the existence of a relationship and forming bonds (i.e., mutual respect and understanding). A study by Bowden and Wood (2011) also confirmed the idea that student's affective and emotional bonds with their university predict student loyalty (behavior).

\subsubsection{Satisfaction}

In line with research on perceived quality by Zeithaml et al. (2009), our assumption was that satisfaction with the overall quality of the performance of faculty/staff would be important for student engagement (H1e). Kuh (2009), for instance, stated that student engagement is 'the time and effort students devote to activities that are empirically linked to desired outcomes of college and what institutions do to induce students to participate in these activities' (p. 683). However, no statistically significant association was found with student engagement. Based on feedback received via the open-ended question in the survey, no valid explanation could be found for the lack of relation between satisfaction and the dimensions of student engagement. Further research is needed to investigate the sequence of relationship quality dimensions and their (educational) consequences.

\subsection{Student engagement}

The idea was that students' evaluation of their engagement in studying would be related to their loyalty (in terms of attitude and/ or behavior) towards their institution and/or educational faculty/staff. This study's findings confirm that student engagement's dimensions dedication and vigor have a statistically significant association with student loyalty. Furthermore, affective commitment had an indirect effect on student loyalty through dedication and vigor.

\subsubsection{Absorption}

Absorption was not statistically significantly positively related to student loyalty (H2a). However, although it failed to reach statistical significance, there was a positive trend between absorption and loyalty. Apparently, in this study's sample, even if students are more absorbed in their studies, this does not statistically significantly affect students' loyal attitude and/or behavior. In other 
words, students might be very enthusiastic about what they are studying. However, this does not necessarily lead to another positive state of mind in terms of loyal affections or (intentions for) behavior towards their educational faculty/staff or university. Perhaps absorption is an over-stated variable to use in students' evaluations of engagement and stretches too far.

\subsubsection{Dedication}

Dedication was positively related to student loyalty (H2b \& c) and trust in honesty and affective commitment had an indirect effect on loyalty through dedication (H4b \& c). There seems to be a strong connection between students' dedication to their studies and their affective commitment to their educational faculty/staff, their trust in the honesty of their educational faculty/staff, and their experienced lack of affective conflict. Perhaps the idea that commitment - through its influence on dedication - might act as a precursor for loyalty also holds in a higher educational context (see commitment-trust theory; Morgan \& Hunt, 1994); student engagement in the form of dedication has a positive statistically significant direct influence on student loyalty, and also partially mediates the relations of affective commitment, and affective conflict with loyalty. Furthermore, elaborating on relationship research (e.g., Tschannen-Moran \& Gareis, 2015), due to the presence of student's dedication to study, trust in honesty may positively influence student loyalty (H1b). This is an interesting finding for faculty/staff who want to incorporate these ideas within the guidance they give to students (e.g., via communication/feedback to students). Honest reactions to students seem to evoke positive and loyal intentions and behavior.

\subsubsection{Vigor}

Vigor was positively related to student loyalty affective commitment and affective conflict had an indirect effect on student loyalty through vigor. Induced by affective commitment and affective conflict, it seems that the more students feel vigorous at their studies (H2c), the more they will develop a loyal attitude towards their institution and/or faculty/staff (e.g., intentions or willingness to be present at institutional open house days), and/or show loyal behavior (e.g., giving positive recommendations). This could be due to the interpersonal relations students build and establish at school, such as with their educational faculty and staff. However, they also might feel positive to be at school in general because they like being there to work on their studies for instance with their peers and fellow students.

\section{Implications, limitations \& future research}

This study's findings have implications for educational practitioners and policymakers. By focusing on students' expectations and monitoring factors that influence the educational experience, for instance, by showing positive responses to students in terms of helpfulness behavior (i.e., willing to be of assistance and giving feedback), institutions of higher education may positively influence the quality of the relationship with their students. In other words, ensuring educational faculty/staffs' sincerity in their guidance to students and reducing students' feelings of (affective) conflict, could help establish positive fruitful relationships between educational faculty/staff and students. In turn, this could be beneficial for HEIs and their educational faculty/staff (e.g., student retention; O'Keeffe, 2013; completion rates; Estermann \& Claeys-Kulik, 2016; Jones, 2016; positive reflection on job satisfaction; Kim \& Schallert, 2011; Veldman et al., 2013; and sense of belonging; Kim \& Lundberg, 2016). By building relationships with students in such a way, HEIs could be rewarded with student loyalty.

Although this study contributes to the body of knowledge of student-faculty relationship quality and the importance of building relationships with students, it has its limitations. First, this study was an initial attempt to identify key drivers of student engagement and in turn, student loyalty, which means that, although we used validated scales to test our hypothesized model and thereby increased its validity, the relations are only correlational; causal relations cannot be indicated. Parallel to quantitative research, to provide a broader view on relational bonds between students and their educational faculty and staff, a qualitative approach could be useful to gain further insight into relationship quality in higher education. Future research may focus on the examination of the way how students and educational faculty and staff perceive their relationship quality for instance by data collected among enrolled students, asking them to describe positive and negative experiences related to the quality of their relationships with educational faculty and staff or their university in general. Second, this study's sample consisted of students from one university of applied sciences. One could replicate the study by including students from other universities in other courses of study, or also examine differences between male and female students.

Furthermore, the research design did not rule out the possibility that the directionality of the relation between relationship quality and student engagement may go the other way or be bi-directional. In this study, the educational faculty/staff's perceptions of the relationship quality were also not included.

In this study, the focus was on positive student-faculty relationship quality dimensions as key drivers for the dimensions of student engagement, and, in turn, for student loyalty. The contribution of this study lies in the fact that it provides new insights into possible influences on students' educational experiences related to their bonds with educational faculty/staff. The assumptions were that having high-quality relationships with students will positively influence their academic involvement in terms of student engagement, and in turn their student loyalty. Although the model explained $55 \%$ of the variance in student loyalty, $45 \%$ of the variance in student loyalty was still unexplained. Dimensions of relationship quality and student engagement explained part of the variance of student loyalty and are therefore to be considered important drivers of student loyalty. To further examine other drivers of student loyalty, future research should include possible alternative predictors such as the institutional image (Brown \& Mazzarol, 2009) or perceived value of education (Ledden, Kalafatis, \& Samouel, 2007; Woodall et al., 2012). Recent studies have investigated academic performance or a derivative thereof (e.g., academic achievement, academic, study, student, or school success) in relation to 
student engagement (Bakker et al., 2015). In this study, academic performance was not included in the model because of the crosssectional design. However, academic performance could be of interest, for example, the association between student engagement and academic performance (Bakker et al., 2015). Prior research has indicated that the grades students earn are expected to be the most important indicator for success in future studies (Pascarella \& Terenzini, 2005).

Another possibility for future longitudinal research would be to gain insight into the extent to which relationship quality and students' intentions and behavior develop over time. In line with this, alumni also form an interesting group to investigate (e.g.,; McAlexander, Koenig, \& Schouten, 2006;Snijders et al., 2019) Alumni can offer valuable insights regarding their current professional requirements and how well their former program prepared them for those requirements. Alumni loyalty could be expressed by (satisfied) alumni, who are likely to give financial donations to their university or provide positive word-of-mouth communication. In addition, using other kinds of indicators (e.g., behavioral indicators) instead of relying only on self-report could be of interest for examining student engagement and student loyalty.

\section{Conclusion}

Through the lens of social exchange theory applied in a higher education context, this study investigated students' perceptions of the quality of the relationship with their educational faculty and staff and its associations with student engagement, and student loyalty. Based on these findings, this study suggests that a relationship management approach is fruitful for higher education policymakers. They should focus on building and nurturing student/institutional relationships due to their positive effect on student engagement and student loyalty. Educational faculty and staff should be aware of relationship quality aspects. Moreover, they need to consider and elaborate on students' evaluations of the quality of their relationships with educational faculty and staff, and, should discuss students' perceptions within the educational faculty and staff's team. A one-size-fits-all approach will not work, so they need to learn what individual students' relational needs are. Therefore, it is essential to evaluate students' needs regularly, and consider relationship quality dimensions as suggested within this study. Including these dimensions in educational and faculty/staff's way of guidance, such as by providing honest feedback towards students, showing care and concern, and willingness to help when needed, are good starting points in this respect.

\section{Author note}

The authors presented earlier versions of this paper at the annual meeting of the American Educational Research Association, San Antonio, (TX), USA, in April 2017, at the biannual meeting of the European Association for Research on Learning and Instruction, Tampere, Finland, August 2017, and at the Biennial International Seminar on the Teaching of Psychological Science, Paris, France, July 2018.

\section{Declaration of Competing Interest}

The authors declare that they have no conflict of interest

\section{Acknowledgements}

This study was funded by the Netherlands Organisation for Scientific Research (NWO) under grant number 023.006.035. The authors would like to thank Dr. Emily Fox and anonymous reviewers for their comments on this paper.

\section{Appendix A}

Table A1

(In)direct Effects after Bootstrapping Procedure.

\begin{tabular}{lccc}
\hline Relation & Sample Mean $(M)^{\text {a }}$ & $t$ Statistics $($ O/STDEV) & $p$ Values \\
\hline H1a: RQT_B - > SE_AB & .100 & 1.364 & .173 \\
H1a: RQT_B - > SE_DE & -.019 & .255 & .799 \\
H1a: RQT_B - S SE_VI & -.015 & .212 & .538 \\
H1b: RQT_H - > SE_AB & -.036 & 2.132 & .532 \\
H1b: RQT_H - > SE_DE & .150 & .637 & .033 \\
H1b: RQT_H - > SE_VI & -.042 & 8.621 & .524 \\
H1c: RQACOMM - S SE_AB & .475 & 9.247 & .000 \\
H1c: RQACOMM - S SE_DE & .480 & 9.631 & .000 \\
H1c: RQACOMM - > SE_VI & .465 & 2.076 & .000 \\
H1d: RQACON - > SE_AB & -.102 & 1.883 & .036 \\
H1d: RQACON - > SE_DE & -.080 & 5.524 & .060 \\
H1d: RQACON - > SE_VI & -.258 & .298 & .000 \\
H1e: RQSAT - > SE_AB & -.019 & & .765
\end{tabular}


Table A1 (continued)

\begin{tabular}{|c|c|c|c|}
\hline Relation & Sample Mean $(M)^{\mathrm{a}}$ & $t$ Statistics (O/STDEV) & $p$ Values \\
\hline H1e: RQSAT -> SE_DE & .092 & 1.527 & .127 \\
\hline H1e: RQSAT - > SE_VI & .051 & .822 & .411 \\
\hline H2 a: SE_AB- > SL & -.107 & 1.936 & .053 \\
\hline H2 b: SE_DE- > SL & .683 & 13.728 & .000 \\
\hline H2 c: SE_VI- > SL & .192 & 3.294 & .001 \\
\hline H3 a: RQT_B -> SL & .016 & .273 & .785 \\
\hline H3 b: RQT_H -> SL & .224 & 3.985 & .000 \\
\hline H3 c: RQACOMM -> SL & .328 & 9.052 & .000 \\
\hline H3 d: RQACON -> SL & -.130 & 3.518 & .000 \\
\hline H3 e: RQSAT -> SL & .221 & 4.069 & .000 \\
\hline H4 a: RQT_B - > SE_AB -> SL & -.011 & 1.057 & .290 \\
\hline H4 a: RQT_B -> SE_DE -> SL & -.013 & .255 & .799 \\
\hline H4 a: RQT_B -> SE_VI -> SL & -.003 & .205 & .838 \\
\hline H4 b: RQT_H -> SE_AB -> SL & .004 & .447 & .655 \\
\hline H4 b: RQT_H -> SE_DE -> SL & .102 & 2.087 & .037 \\
\hline H4 b: RQT_H - > SE_VI -> SL & -.008 & .604. & .546 \\
\hline H4 c: RQACOMM -> SE_AB -> SL & -.051 & 1.841 & .066 \\
\hline H4 c: RQACOMM - > SE_DE -> SL & .328 & 7.324 & .000 \\
\hline H4 c: RQACOMM - > SE_VI - > SL & .089 & 3.003 & .003 \\
\hline H4 d: RQACON -> SE_AB -> SL & .011 & 1.334 & .182 \\
\hline H4 d: RQACON -> SE_DE -> SL & -.54 & 1.870 & .062 \\
\hline H4 d: RQACON -> SE_VI -> SL & -.050 & 2.813 & .005 \\
\hline H4 e: RQSAT -> SE_AB - > SL & .002 & .257 & .797 \\
\hline H4 e: RQSAT - > SE_DE - > SL & .063 & 1.504 & .133 \\
\hline H4 e: RQSAT - > SE_VI - > SL & .010 & .769 & .442 \\
\hline
\end{tabular}

Note. RQACOMM = Relationship Quality Affective Commitment; RQACON = Relationship Quality Affective Conflict; RQSAT = Relationship Quality Satisfaction; RQT_B = Relationship Quality Trust in Benevolence; RQT_H = Relationship Quality Trust in Honesty; SE_AB = Student Engagement Absorption; SE_DE = Student Engagement Dedication; SE_VI = Student Engagement Vigor, and SL $=$ Student Loyalty.

a Sample mean values represent the bootstrap estimates on average.

\section{Appendix B. Supplementary data}

Supplementary material related to this article can be found, in the online version, at doi:https://doi.org/10.1016/j.ijer.2020. 101538.

\section{References}

Alves, H., \& Raposo, M. (2007). Conceptual model of student satisfaction in higher education. Total Quality Management \& Business Excellence, 18, 571-588. https://doi. org/10.1080/14783360601074315.

Anderson, J. C., \& Gerbing, D. W. (1988). Structural equation modeling in practice: A review and recommended two-step approach. Psychological Bulletin, 103, 411-423. https://doi.org/10.1037//0033-2909.103.3.411.

Astin, A. W. (1993). What matters in college? Four critical years revisited. 22(8). San Francisco, CA: Jossey-Bass.

Atnip, B. R. K. (2015). Assessing the relationship between student and faculty perceptions of student engagement at Central Mountain College (Doctoral dissertation). Retrieved fromhttp://digitalcommons.unl.edu/cehsedaddiss/219/.

Bakker, A. B., Sanz Vergel, A. I., \& Kuntze, J. (2015). Student engagement and performance: A weekly diary study on the role of openness. Motivation and Emotion, 39, 49-62. https://doi.org/10.1007/s11031-014-9422-5.

Betts, J. E., Appleton, J. J., Reschly, A. L., Christenson, S. L., \& Huebner, E. S. (2010). A study of the factorial invariance of the Student Engagement Instrument (SEI): Results from middle and high school students. School Psychology Quarterly, 25, 84-93. https://doi.org/10.1037/a0020259.

Bowden, J. L. H. (2009). The process of customer engagement: A conceptual framework. The Journal of Marketing Theory and Practice, 17, 63-74. https://doi.org/10. 2753/MTP1069-6679170105.

Bowden, J. L. H. (2011). Engaging the student as a customer: A relationship marketing approach. Marketing Education Review, 21, 211-228. https://doi.org/10.2753/ mer1052-8008210302.

Bowden, J., \& Wood, L. (2011). Sex doesn't matter: The role of gender in the formation of student-University relationships. Journal of Marketing for Higher Education, 21(2), 133-156. https://doi.org/10.1080/08841241.2011.623731.

Braun, J., \& Zolfagharian, M. (2016). Student participation in academic advising: Propensity, behavior, attribution and satisfaction. Research in Higher Education, 57, 968-989. https://doi.org/10.1007/s11162-016-9414-2.

Brown, R. M., \& Mazzarol, T. (2009). The importance of institutional image to student satisfaction and loyalty within higher education. Higher Education, 58, 81-95. https://doi.org/10.1007/s10734-008-9183-8.

Bunce, L., Baird, A., \& Jones, S. E. (2017). The student-as-consumer approach in higher education and its effects on academic performance. Studies in Higher Education, 42(11), 1958-1978. https://doi.org/10.1080/03075079.2015.1127908.

Buttle, F., \& Maklan, S. (2015). Customer relationship management: Concepts and technologies. New York, NY: Routledge.

Carvalho, S. W., \& de Oliveira Mota, M. (2010). The role of trust in creating value and student loyalty in relational exchanges between higher education institutions and their students. Journal of Marketing for Higher Education, 20, 145-165. https://doi.org/10.1080/08841241003788201.

Chirikov, I. (2016). How global competition is changing universities: Three theoretical perspectives. Research and occasional paper series, center for studies in higher education. Retrieved from https://escholarship.org/uc/item/50g3t797. 
Cohen, J. (1988). Statistical power analysis for the behavioral sciences (2nd ed.)). Hillsdale, NJ: Lawrence Earlbaum Associates.

Connell, J. P., \& Wellborn, J. G. (1991). Competence, autonomy, and relatedness: A motivational analysis of self-system processes. In R. Gunnar, \& L. A. Sroufe (Vol. Eds.), Self processes and development: The Minnesota symposia on child psychology: Vol. 23, (pp. 43-77). Chicago: Chicago University Press.

Cotten, S., \& Wilson, B. (2006). Student-Faculty interactions: Dynamics and determinants. Higher Education, 51, 487-519. https://doi.org/10.1007/s10734-004$1705-4$.

Crosby, L. A., Evans, K. A., \& Cowles, D. (1990). Relationship quality in services selling: An interpersonal influence perspective. Journal of Marketing, 54(3), 68-81. https://doi.org/10.2307/1251817.

Dick, A. S., \& Basu, K. (1994). Customer loyalty: Toward an integrated conceptual framework. Journal of the Academy of Marketing Science, 22(2), 99-113. https://doi. org $/ 10.1177 / 0092070394222001$.

Elken, M., Hovdhaugen, E., \& Stensaker, B. (2016). Global rankings in the Nordic region: challenging the identity of research-intensive universities? Higher Education, 72, 781-795. https://doi.org/10.1007/s10734-015-9975-6.

Estermann, T., \& Claeys-Kulik, A. L. (2016). Performance-based funding of universities in Europe. International Higher Education, 85, 31-33. https://doi.org/10.6017/ ihe.2016.85.9250.

Fornell, C., \& Larcker, D. F. (1981). Structural equation models with unobservable variables and measurement error: Algebra and statistics. Journal of Marketing Research, 18, 382-388. https://doi.org/10.2307/3150980.

Fraser, B. J., \& Walberg, H. J. (2005). Research on teacher-Student relationships and learning environments: Context, retrospect and prospect. International Journal of Educational Research, 43, 103-109. https://doi.org/10.1016/j.ijer.2006.03.001.

Fredricks, J. A., \& McColskey, W. (2012). The measurement of student engagement: A comparative analysis of various methods and student self-report instruments. In S. Christenson, A. L. Reschly, \& C. Wylie (Eds.). Handbook of research on student engagement (pp. 763-782). Boston, MA: Springer.

Fredricks, J. A., Filsecker, M., \& Lawson, M. A. (2016). Student engagement, context, and adjustment: Addressing definitional, measurement, and methodological issues. Learning and Instruction, 43, 1-4. https://doi.org/10.1016/j.learninstruc.2016.02.002.

Grönroos, C. (1994). Quo vadis, marketing? Toward a relationship marketing paradigm. Journal of Marketing Management, 10, 347-360. https://doi.org/10.1080/ 0267257X.1994.9964283.

Gummesson, E. (1994). Broadening and specifying relationship marketing. Asia-Australia Marketing Journal, 2, 31-43. https://doi.org/10.1016/S1320-1646(94) 70276-8.

Hagedorn, L. S. (2015). A national initiative of teaching, researching, and dreaming: Community college faculty research in "achieving the Dream" colleges. New Directions for Community Colleges, 171, 49-62. https://doi.org/10.1002/cc.20154.

Hagenauer, G., \& Volet, S. A. E. (2014). Teacher-Student relationship at university: An important yet under-researched field. Oxford Review of Education, 40, 370-388. https://doi.org/10.1080/03054985.2014.921613.

Hair, J. F., Jr., Hult, G. T. M., Ringle, C., \& Sarstedt, M. (2016). A primer on partial least squares structural equation modeling (PLS-SEM). Thousand Oaks, CA: Sage.

Hair, J. F., Jr., Hult, G. T. M., Ringle, C., \& Sarstedt, M. (2017). A primer on partial least squares structural equation modeling (PLS-SEM) (Second edition). Thousand Oaks, CA: Sage.

Hallowell, R. (1996). The relationships of customer satisfaction, customer loyalty, and profitability: An empirical study. International Journal of Service Industry Management, 7(4), 27-42. https://doi.org/10.1108/09564239610129931.

Hennig-Thurau, T., Langer, M., \& Hansen, U. (2001). Modeling and managing student loyalty: An approach based on the concept of relationship quality. Journal of Service Research, 3, 331-344. https://doi.org/10.1177/109467050134006.

Hu, Y. L., Hung, C. H., \& Ching, G. S. (2014). Student-faculty interaction: Mediating between student engagement factors and educational outcome gains. International Journal of Research Studies in Education, 4(1), 43-53. https://doi.org/10.5861/ijrse.2014.800.

Jang, H., Reeve, J., \& Deci, E. L. (2010). Engaging students in learning activities: It is not autonomy support or structure but autonomy support and structure. Journal of Educational Psychology, 102, 588-600. https://doi.org/10.1037/a0019682.

Jarvis, W., Halvorson, W., Sadeque, S., \& Johnston, S. (2014). A large class engagement (LCE) model based on service-dominant logic (SDL) and flipped classrooms. Education Research and Perspectives, 41, 1-24. Retrieved from http://www.erpjournal.net.

Jones, D. P. (2016). Outcomes-based funding: Taking stock. Washington, DC: National Center for Higher Education Management Systems and Delta Project on Postsecondary Costs, Productivity, and Accountability.

Kahu, E. R. (2013). Framing student engagement in higher education. Studies in Higher Education, 38, 758-773. https://doi.org/10.1080/03075079.2011.598505.

Kim, Y. K., \& Lundberg, C. A. (2016). A structural model of the relationship between student-faculty interaction and cognitive skills development among college students. Research in Higher Education, 57(3), 288-309. https://doi.org/10.1007/s11162-015-9387-6.

Kim, Y. K., \& Sax, L. J. (2009). Student-Faculty interaction in research universities: Differences by student gender, race, social class, and first-generation status. Research in Higher Education, 50, 437-459. https://doi.org/10.1007/s11162-009-9127-x.

Kim, M., \& Schallert, D. L. (2011). Building caring relationships between a teacher and students in a teacher preparation program word-by-word, moment-by-moment. Teaching and Teacher Education, 27, 1059-1067. https://doi.org/10.1016/j.tate.2011.05.002.

Klem, A. M., \& Connell, J. P. (2004). Relationships matter: Linking teacher support to student engagement and achievement. The Journal of School Health, 74, 262-273. https://doi.org/10.1111/j.1746-1561.2004.tb08283.x.

Kuh, G. D. (2009). What student affairs professionals need to know about student engagement. Journal of College Student Development, 50(6), 683-706. https://doi.org/ $10.1353 /$ csd.0.0099.

Kuh, G., \& Hu, S. (2001). The effects of student-faculty interaction in the 1990s. The Review of Higher Education, 24(3), 309-332. https://doi.org/10.1353/rhe.2001. 0005 .

Kumar, N., Scheer, L. K., \& Steenkamp, J. B. E. (1995). The effects of perceived interdependence on dealer attitudes. Journal of Marketing Research, 32(3), 348-356.

Ledden, L., Kalafatis, S. P., \& Samouel, P. (2007). The relationship between personal values and perceived value of education. Journal of Business Research, 60, 965-974. https://doi.org/10.1016/j.jbusres.2007.01.021.

Lee, J. S. (2012). The effects of the teacher-student relationship and academic press on student engagement and academic performance. International Journal of Educational Research, 53, 330-340. https://doi.org/10.1016/j.ijer.2012.04.006.

Macintosh, G. (2007). Customer orientation, relationship quality, and relational benefits to the firm. Journal of Services Marketing, 21, 150-159. https://doi.org/10. 1108/08876040710746516.

McAlexander, J. H., Koenig, H. F., \& Schouten, J. W. (2006). Building relationships of brand community in higher education: A strategic framework for university advancement. International Journal of Educational Advancement, 6, 107-118. https://doi.org/10.1057/palgrave.ijea.2150015.

McManus, J., \& Mosca, J. (2015). Strategies to build trust and improve employee engagement. International Journal of Management \& Information Systems (IJMIS), 19(1), 37-42. https://doi.org/10.19030/ijmis.v19i1.9056.

Meeuwisse, M., Severiens, S. E., \& Born, M. P. (2010). Learning environment, interaction, sense of belonging and study success in ethnically diverse student groups. Research in Higher Education, 51(6), 528-545. https://doi.org/10.1007/s11162-010-9168-1.

Morgan, R. M., \& Hunt, S. D. (1994). The commitment-trust theory of relationship marketing. Journal of Marketing, 58(3), 20-38. https://doi.org/10.2307/1252308.

Nesset, E., \& Helgesen, Ø. (2009). Modelling and managing student loyalty: A study of a Norwegian university college. Scandinavian Journal of Educational Research, 53, 327-345. https://doi.org/10.1080/00313830903043117.

Ng, I. C. L., \& Forbes, J. (2009). Education as service: The understanding of university experience through the service logic. Journal of Marketing for Higher Education, 19, 38-64. https://doi.org/10.1080/08841240902904703.

O'Keeffe, P. (2013). A sense of belonging: Improving student retention. College Student Journal, 47, 605-613. Retrieved from http://www.ingentaconnect.com/ content/prin/csj.

Osobajo, O. A., \& Moore, D. (2017). Methodological choices in relationship quality (RQ) research 1987 to 2015: A systematic literature review. Journal of Relationship Marketing, 1(16), 40-81. https://doi.org/10.1080/15332667.2016.1242395. 
Pascarella, E. T., \& Terenzini, P. T. (2005). How college affects students: A third decade of research, Vol. 2. San Francisco: Jossey-Bass.

Pascarella, E. T., Terenzini, P. T., \& Hibel, J. (1978). Student-faculty interactional settings and their relationship to predicted academic performance. The Journal of Higher Education, 49(5), 450-463. Retrieved from: http://www2.ccga.edu/oie/files/StudentSuccessNewsletterFall2013.pdf.

Perin, M. G., Sampaio, C. H., Simões, C., \& de Pólvora, R. P. (2012). Modeling antecedents of student loyalty in higher education. Journal of Marketing for Higher Education, 22, 101-116. https://doi.org/10.1080/08841241.2012.705797.

Pianta, R. C., Hamre, B. K., \& Allen, J. P. (2012). Teacher-student relationships and engagement: Conceptualizing, measuring, and improving the capacity of classroom interactions. In S. Christenson, A. L. Reschly, \& C. Wylie (Eds.). Handbook of research on student engagement (pp. 365-386). Boston, MA: Springer.

Ringle, C. M., Wende, S., \& Becker, J. (2015). SmartPLS 3. Retrieved fromBönningstedt: SmartPLS. http://www.smartpls.com.

Roberts, K., Varki, S., \& Brodie, R. (2003). Measuring the quality of relationships in consumer services: An empirical study. European Journal of Marketing, 37, 169-196. https://doi.org/10.1108/03090560310454037.

Rojas-Mendez, J. I., Vasquez-Parraga, A. Z., Kara, A., \& Cerda-Urrutia, A. (2009). Determinants of student loyalty in higher education: A tested relationship approach in Latin America. Latin American Business Review, 10, 21-39. https://doi.org/10.1080/10978520903022089.

Schaufeli, W. B., \& Bakker, A. B. (2003). UWES Utrecht work engagement scale. Preliminary manual [Version 1, November 2003]. Utrecht: Occupational Health Psychology Unit, Utrecht University.

Schaufeli, W. B., Bakker, A. B., \& Salanova, M. (2006). The measurement of work engagement with a short questionnaire: A cross-national study. Educational and Psychological Measurement, 66, 701-716. https://doi.org/10.1177/0013164405282471.

Schaufeli, W. B., Martinez, I. M., Marques Pinto, A., Salanova, M., \& Bakker, A. B. (2002). Burnout and engagement in university students: A cross-national study. Journal of Cross-cultural Psychology, 33, 464-481. https://doi.org/10.1177/0022022102033005003.

Sung, M., \& Yang, S. U. (2009). Student-University relationships and reputation: A study of the links between key factors fostering students' supportive behavioral intentions towards their university. Higher Education, 57, 787-811. https://doi.org/10.1007/s10734-008-9176-7.

Snijders, I., Rikers, R. M. J. P., Wijnia, L., \& Loyens, S. M. M. (2018). Relationship Quality Time: the validation of a relationship quality scale in higher education. Higher Education Research \& Development, 37(2), 404-417. https://doi.org/10.1080/07294360.2017.1355892.

Snijders, I., Wijnia, L., Rikers, R. M. J. P., \& Loyens, S. M. M. (2019). Alymni loyalty drivers in higher education. Social Psychology of Education, 22(3), 606-627. https://doi.org/10.1007/s11218-019-09488-4.

Taylor, L., \& Parsons, J. (2011). Improving student engagement. Current Issues in Education, 14(1), Retrieved from http://cie.asu.edu/.

Temmerman, N. (2018). The importance of listening to university stakeholders. University world news, the global window on higher education. 18 April Retrieved from:https://www.universityworldnews.com/post.php?story = 20180410151237739.

Tomlinson, M. (2017). Student perceptions of themselves as 'consumers' of higher education. British Journal of Sociology of Education, 38(4), 450-467. https://doi.org/ $10.1080 / 01425692.2015 .1113856$.

Tschannen-Moran, M., \& Gareis, C. R. (2015). Principals, trust, and cultivating vibrant schools. Societies, 5, 256-276. https://doi.org/10.3390/soc5020256.

Umbach, P. D., \& Wawrzynski, M. R. (2005). Faculty do matter: The role of college faculty in student learning and engagement. Research in Higher Education, 46(2), 153-184. https://doi.org/10.1007/s11162-004-1598-1.

Van Doorn, J., Lemon, K. N., Mittal, V., Nass, S., Pick, D., Pirner, P., et al. (2010). Customer engagement behavior: Theoretical foundations and research directions. Journal of Service Research, 13, 253-266. https://doi.org/10.1177/1094670510375599.

Veldman, I., Van Tartwijk, J., Brekelmans, M., \& Wubbels, T. (2013). Job satisfaction and teacher-Student relationships across the teaching career: Four case studies. Teaching and Teacher Education, 32, 55-65. https://doi.org/10.1016/j.tate.2013.01.005.

Verhoef, P. C., Reinartz, W. J., \& Krafft, M. (2010). Customer engagement as a new perspective in customer management. Journal of Service Research, 13, 247-252. https://doi.org/10.1177/1094670510375461.

Wentzel, K. (2018). How student-teacher relationships impact student engagement and learning. [Audio podcast Critical Window from the Alliance for Excellent Education]. 20 November Retrieved fromhttps://all4ed.org/when-students-trust-their-teachers/.

Wilkins, C. H. (2018). Effective engagement requires trust and being trustworthy. Medical Care, 56(10 Suppl 1), S6. https://doi.org/10.1097/MLR. 0000000000000953. Retrieved from: https://www.ncbi.nlm.nih.gov/pmc/articles/PMC6143205/.

Wong, T. K., Parent, A. M., \& Konishi, C. (2019). Feeling connected: The roles of student-teacher relationships and sense of school belonging on future orientation. International Journal of Educational Research, 94, 150-157.

Woodall, T., Hiller, A., \& Resnick, S. (2012). Making sense of higher education: Students as consumers and the value of the university experience. Studies in Higher Education, 39, 48-67. https://doi.org/10.1080/03075079.2011.648373.

Wubbels, T., \& Brekelmans, M. (2005). Two decades of research on teacher-student relationships in class. International Journal of Educational Research, 43(1-2), 6-24.

Xerri, M. J., Radford, K., \& Shacklock, K. (2017). Student engagement in academic activities: A social support perspective. Higher Education, 1-17. https://doi.org/10. 1007/s10734-017-0162-9.

Zeithaml, V. A., Bitner, M. J., \& Gremler, D. D. (2009). Services marketing: Integrating customer focus across the firm. New York, NY: McGraw-Hill Irwin. 